\title{
PENDISTRIBUSIAN PELAKSANAAN BONGKAR MUAT MUATAN AVTUR DI MT. SINAR EMAS
}

\author{
Suwiyadi $^{\mathrm{a}}$, Sri Murdiwati ${ }^{\mathrm{b}}$ dan Bella Octavia Sahara $^{\mathrm{c}}$ \\ ${ }^{a}$ Dosen Program Studi Nautika PIP Semarang \\ ${ }^{b}$ Dosen Program Studi KALK PIP Semarang \\ ${ }^{\mathrm{c}}$ Taruni (NIT.50134835.N) Program Studi Nautika PIP Semarang
}

\begin{abstract}
ABSTRAK
Tujuan utama dalam pelayaran adalah mendistribusikan proses bongkar muat muatan avtur di 3 pelabuhan bongkar. Dalam mencapai tujuan tersebut dapat ditentukan dari langkah-langkah yang dilakukan untuk mendistribusikan muatan avtur, besar jumlah muatan yang dimuat dan dibongkar, dan perhitungan perbedaan jumlah muatan avtur yang dibongkar. Metode penelitian yang digunakan oleh peneliti untuk mengatasi masalah adalah metode kualitatif, kuantitatif dengan metode analisis data Urgency, Seriousness, and Growth (USG) untuk menentukan masalah prioritas saat mendistribusikan bongkar muat muatan avtur sehingga peneliti bisa menemukan pemecahan masalah tersebut. Hasil penelitian menunjukan langkah-langkah yang dilakukan dengan melakukan persiapan fisik dan administrassi, perencanaan pembuatan stowage plan, koordinasi intern dan extern, pelaksanaan distribusi bongkar muat muatan, dan evaluasi melalui perhitungan muatan. Besar muatan avtur yang dimuat dan dibongkar di kapal MT. Sinar Emas berbeda jumlahnya disetiap pelabuhan bongkar karena berdasarkan jumlah muatan yang dibutuhkan dan adanya perbedaan antara pihak darat maupun pihak kapal, keadaan tangki, pipa muatan, penguapan serta adanya kebocoran. Dari hasil penelitian dapat disimpulkan bahwa pada setiap pelabuhan dan daerah membutuhkan muatan avtur yang berbeda-beda dengan proses yang sama serta kecepatan waktu bongkar di setiap pelabuhan juga berbeda-beda.
\end{abstract}

Kata kunci: analisis, distribusi, muat, bongkar, avtur

\section{PENDAHULUAN}

Indonesia merupakan negara maritim atau kepulauan terbesar di dunia, 2/3 wilayahnya merupakan wilayah lautan. Indonesia juga sebagai negara yang mempunyai banyak pulau. Lima pulau terbesar di Indonesia adalah Pulau Jawa, Pulau Kalimantan, Pulau Sulawesi, Pulau Sumatera, dan Pulau Papua. Jumlah pulau di Indonesia tahun 2004 adalah sebanyak 17.504 buah. 7.870 pulau diantaranya telah mempunyai nama, sedangkan 9.634 pulau belum memiliki nama. Pulau satu dengan pulau yang lain dipisahkan oleh laut. Sarana transportasi untuk menghubungkan pulau satu dengan pulau yang lain dibutuhkan transportasi laut yaitu kapal.
Transportasi berasal dari kata transportation, dalam Bahasa Inggris yang memiliki arti angkutan, atau dapat pula berarti suatu proses pemindahan manusia atau barang dari suatu tempat ke tempat lain dengan menggunakan suatu alat bantu kendaraan darat, laut, maupun udara. Transportasi laut adalah pemindahan barang/sesuatu/orang dari pelabuhan tolak menuju pelabuhan tiba menggunakan kapal.

Peranan pengangkutan sangat penting bagi kehidupan sosial ekonomi penduduk Indonesia. Dengan tercapainya peranan pengangkutan, masyarakat Indonesia dapat meningkatkan pertumbuhan ekonomi dan kemajuan teknologi yang berkembang 
dengan pesat karena pengangkutan berperan sekali dalam menciptakan suatu pola distribusi nasional yang dinamis. Pengangkutan yaitu memindahkan barangbarang atau penumpang (orang) dari tempat asal ke tempat tujuan tertentu.

Kapal tanker adalah salah satu sarana transportasi laut yang merupakan alat untuk mengangkut muatan cair atau pengangkutan muatan minyak hasil bumi baik minyak jadi atau minyak mentah, tetapi konstruksi kapal jenis ini juga berbeda-beda, tingkat ketahanan tangki-tangkinya juga disesuaikan dengan tingkat reaksi yang ditimbulkan oleh muatan yang diangkut yaitu kapal tanker yang mengangkut muatan cair jenis minyak mentah, minyak jadi, minyak kelapa atau cairan lain dari satu pelabuhan muat ke pelabuhan bongkar.

Kapal tanker mengangkut minyak bumi yang dapat diolah menjadi jenis bahan bakar, salah satunya adalah avtur. Avtur adalah salah satu jenis bahan bakar berbasis minyak bumi yang berwarna bening hingga kekuning-kuningan,memiliki rentang titik didih antara $145^{\circ} \mathrm{C}$ hingga $300^{\circ} \mathrm{C}$, dan digunakan sebagai bahan bakar pesawat terbang. Dari muatan avtur tersebut akan disalurkan ke pelabuhan dan akan digunakan dalam bahan bakar pesawat terbang. Karena sekarang pemakaian bahan bakar avtur mulai tinggi, oleh karena itu pelabuhan udara di Indonesia semakin diperbanyak.

Pelabuhan udara (Bandara) di Indonesia yang terbesar antara lain: Jakarta (SoekarnoHatta), Surabaya (Juanda), Medan (Polonia) dan Makassar (Sultan Hasanuddin). Bandara yang dijadikan peneliti sebagai objek penelitian ialah Bandara Soekarno-Hatta (Soetta) Jakarta, Juanda Surabaya dan Pattimura Ambon. Ketiga Bandara tersebut tentunya membutuhkan pasokan avtur dalam jumlah banyak. Kebutuhan avtur diketiga bandara tersebut adalah Juanda Surabaya rata-rata $925 \mathrm{KL} /$ hari, Pattimura Ambon rata-rata $75 \mathrm{KL} /$ hari dan Soetta Jakarta sekitar $5.000 \mathrm{KL} /$ hari.

Melihat pentingnya masalah di atas, maka penulis tertarik untuk mengadakan penelitian dengan judul "Pendistribusian Pelaksanaan Bongkar Muat Muatan Avtur di Kapal MT. Sinar Emas".

\section{METODE PENELITIAN}

Metode penelitian yang digunakan adalah metode penelitian kualitatif dan kuantitatif dengan proses sekuensial. Metode kuantitatif menggunakan teknik analisis data Urgency, Seriousness, and Growth (USG). Sedangkan penelitian kualitatif menggunakan pengumpulan data lewat observasi, interview, dokumentasi dan study pustaka. Dalam hal ini peneliti melakukan observasi saat peneliti melakukan praktek layar di kapal MT. Sinar Emas. Peneliti juga mengambil gambar guna mendukung keabsahan data dalam penelitian ini.

Populasi penelitian ini adalah data distribusi avtur dari MT. Sinar Emas pada periode Januari-Juli 2016. Sedangkan sampelnya merupakan penelitian yang dilakukan sebanyak 40 kali kegiatan memuat dan membongkar di kapal MT. Sinar Emas.

\section{HASIL PENELITIAN}

Pelaksanaan penelitian dilaksanakan pada saat bulan Januari-Juli 2016. Adapun hasil penelitian sebagai berikut:

1. Prioritas langkah-langkah yang dilakukan untuk mendistribusikan muatan avtur proses bongkar muat di 3 pelabuhan.

Berdasarkan identifikasi langkahlangkah yang dilakukan untuk mendistribusikan muatan avtur proses bongkar muat di 3 pelabuhan, peneliti menentukan skala prioritas masalah pokok pendistribusian dengan metode USG maka akan didapat prioritas masalah pokok pendistribusian muatan avtur proses bongkar muat di 3 pelabuhan sebagai berikut: 
a. Keadaan tangki kapal yang tidak sesuai sehingga tidak diterbitkan dry certificate.

b. Kapasitas tangki yang menyebabkan muatan saat dimuat akan terjadi overflow.

c. Timbulnya bahaya kepada crew kapal akibat crew kapal tidak memakai alat keselamatan dengan benar.

d. Pelaksanaan distribusi bongkar muat muatan avtur tidak sesuai dengan urutan yang sudah ditentukan.

e. Adanya perbedaan perhitungan antara mualim satu beserta loading master dan survyor.

Berdasarkan identifikasi masalah di atas peneliti menganalisa hasil penelitian tersebut dengan cara USG maka akan didapatkan prioritas yang harus mendapatkan perhatian secara khusus. Berikut peneliti membuat sumber olah data untuk memprioritaskan masalah dengan menggunakan metode analisa data USG:

Tabel 1. Hasil penentuan langkah-langkah pelaksanaan yang akan dibahas melalui metode USG

\begin{tabular}{|c|c|c|c|c|c|c|c|c|c|c|}
\hline \multirow{2}{*}{ No } & \multirow{2}{*}{ Masalah } & \multirow{2}{*}{$\begin{array}{c}\text { Analisa } \\
\text { Perband } \\
\text { ingan }\end{array}$} & \multirow{2}{*}{ U } & \multirow{2}{*}{ S } & \multirow{2}{*}{ G } & \multicolumn{4}{|c|}{ Mulai } & \multirow{2}{*}{$\begin{array}{l}\text { Priorit } \\
\text { as }\end{array}$} \\
\hline & & & & & & $\mathrm{U}$ & $\mathrm{S}$ & G & $\mathrm{T}$ & \\
\hline \multirow[t]{4}{*}{ A } & \multirow{4}{*}{$\begin{array}{l}\text { Mempersiapk } \\
\text { an kapal } \\
\text { dengan tank } \\
\text { cleaning } \\
\text { kapal beserta } \\
\text { alat muat dan } \\
\text { bongkar. }\end{array}$} & A-B & A & B & A & \multirow[t]{4}{*}{4} & \multirow[t]{4}{*}{3} & \multirow[t]{4}{*}{4} & \multirow{4}{*}{$\begin{array}{l}1 \\
1\end{array}$} & \multirow[t]{4}{*}{ II } \\
\hline & & A-C & A & C & A & & & & & \\
\hline & & A-D & A & A & A & & & & & \\
\hline & & A-E & A & A & E & & & & & \\
\hline \multirow[t]{3}{*}{ B } & \multirow{3}{*}{$\begin{array}{l}\text { Menyiapkan } \\
\text { perencanaan } \\
\text { dengan } \\
\text { stowage plan } \\
\text { bongkar } \\
\text { sesuai } \\
\text { dengan } \\
\text { permintaan } \\
\text { pada cargo } \\
\text { manifest. }\end{array}$} & B-C & B & B & $\mathrm{C}$ & \multirow[t]{3}{*}{3} & \multirow[t]{3}{*}{3} & \multirow[t]{3}{*}{3} & \multirow[t]{3}{*}{9} & \multirow[t]{3}{*}{ IV } \\
\hline & & B-D & B & B & D & & & & & \\
\hline & & B-E & B & B & B & & & & & \\
\hline $\mathrm{C}$ & Melaksanaka & C-D & D & C & $\mathrm{D}$ & 3 & 2 & 1 & 6 & $\mathrm{~V}$ \\
\hline
\end{tabular}

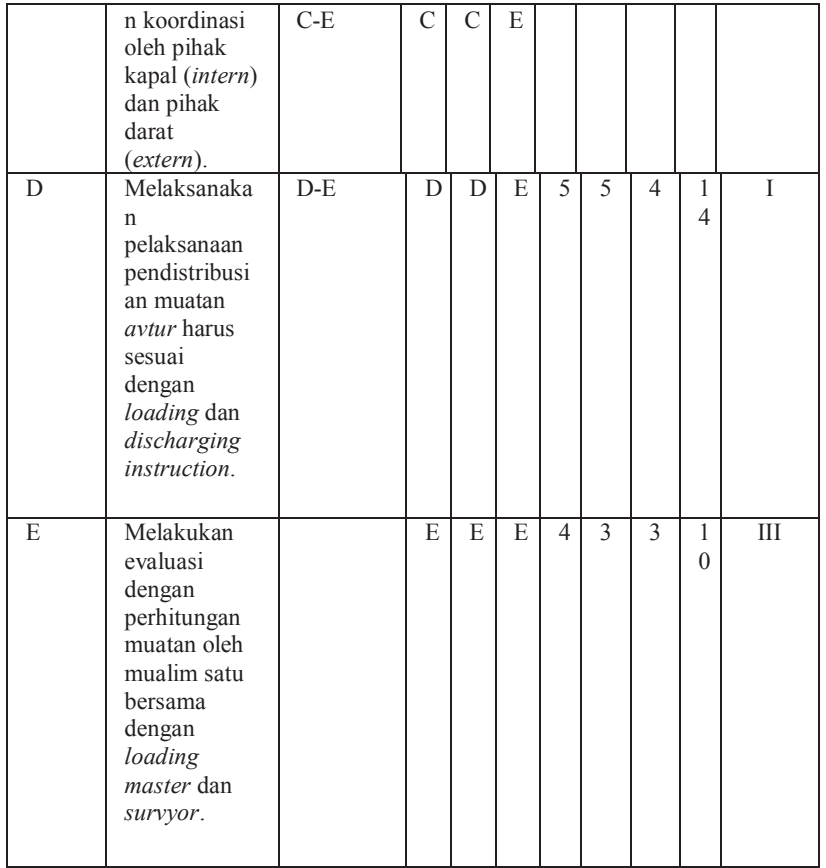

- Pengertian USG

Urgency : adalah masalah yang apabila tidak segera diatasi akan berakibat fatal dalam jangka pendek.

Seriousness : adalah masalah yang apabila terlambat akan berdampak fatal terhadap kegiatan tetap dan berpengaruh pada jangka panjang.

Growth : adalah masalah potensial untuk tumbuh dan berkembangnya masalah baru dalam jangka panjang.

Melihat dari tabel penilaian secara USG tersebut maka diperoleh prioritas berdasarkan tingkat tertinggi yang pernah dialami dan disimpulkan sebagai berikut:

1. Pendistribusian muatan avtur harus sesuai dengan loading dan discharging instruction.

Pendistribusian muatan avtur harus sesuai dengan loading dan discharging instruction merupakan tingkat utama yang harus dilakukan sebelum dan sesudah melakukan proses muat dan bongkar di satu pelabuhan muat dan tiga 
pelabuhan bongkar. Maka dari itu sebagai perwira kapal harus melaksanakan tata cara urutan dalam melaksanakan loading dan discharging instruction di atas kapal. Berikut ini loading dan discharging instruction di MT. Sinar Emas adalah sebagai berikut:

a. MEMUAT

1) Pengecekan sebelum melaksanakan memuat

- Periksa semua garis tambat semuanya dengan baik

- Periksa kawat derek darurat di posisi kanan

- Periksa semua scupper plug sudah tertutup rapat

- Periksa semua baut dan mur rapat dan kencangkan.

- Periksa spill box siap pakai dan tutup steker kering

- Periksalah pompa pencemaran minyak yang siap pakai

- Periksa line yang digunakan, termasuk katupnya

- Periksa kawat pembatas di posisi kanan

- Periksa tidak ada kebocoran di manifold

- Periksa ke semua katup yang dikoreksi

2) Urutan dalam memuat (mencegah polusi)

- ambil sampel manifold dari pemuatan pertama yang masuk ke dalam tangki

- Setelah memuat sebesar satu kaki, lakukan pemberhentian sementara untuk dianalisa

- Initial loading rate dengan maksimal $1 \mathrm{~m} / \mathrm{sec} \quad(113$ $\mathrm{m} 3 / \mathrm{hrs}$ )

- Periksa barang yang sudah masuk ke dalam pelabuhan.

- Memuat avtur +/- $22000 \mathrm{KL}$

- Sebelum tooping up dan tooping off, buka valve ke tangki selanjutnya
- Max. Loading rate adalah $1000 \mathrm{~m} 3 / \mathrm{hrs}$

- - The topping up dan topping off dari muatan avtur bandingkan dengan stowage plan yang telah dibuat

- satu jam sebelum topping up dari masing-masing tangki, hubungi mualim satu

- Hubungi mualim satu jika ada keragu-raguan

3) Tindakan jika over flow

- Hentikan aktivitas memuat dan tutup valve

- Bunyikan alarm

- Temukan keadaan darurat dan bahaya yang sedang terjadi

- Informasikan ke Nakhoda dengan segera

- Informasikan kepada otoritas pelabuhan setempat biasanya melalui staf terminal

- Personil yang tidak penting dari daerah tersebut dilarang untuk mendekat

- Tutup semua pintu akses akomodasi dan hentikan semua ventilasi sirkuit tertutup

- Tim darurat dan tim cadangan, berdiri untuk mengumpulkan/memompa tumpahan cargo ke tangki kosong/slop tank

- Semua tim harus menggunakan setelan kimia dengan benar

- Atur mesin utama dan roda kemudi untuk dibawa ke posisi stand by

4) Komunikasi

- Hubungi pelabuhan darat : hubungi orang yang sedang melakukan dinas jaga saat di pelabuhan

- Terminal darurat : Loading Master VHF Ch. 09. 
- Agen : Operasi Pertamina VHF Ch. 09.

- Pelabuhan Cilacap : Pelabuhan Cilacap VHF Ch. 12.

5) Loading Sequence

- Memuat (+/- $220000 \mathrm{KL})$

- Maksimal rate bongkar (1000 $\mathrm{KL} / \mathrm{hrs}$ ) dan maksimal tekanan memuat $(5 \mathrm{~kg} / \mathrm{cm} 2)$

- Nominasi tangki muatan : $1 \mathrm{P} / \mathrm{S}, 2 \mathrm{P} / \mathrm{S}, 3 \mathrm{P} / \mathrm{S}, 4 \mathrm{P} / \mathrm{S}, 5 \mathrm{P} / \mathrm{S}$, dan $6 \mathrm{P} / \mathrm{S}$

- Tetap dalam posisi menyala atau berjalan untuk semua high \& overfill alarm

- Hentikan memuat dengan segera jika terdapat kebocoran

b. MEMBONGKAR

1) Pengecekan sebelum melaksanakan memuat

- Periksa semua garis tambat semuanya dengan baik.

- Periksa kawat derek darurat di posisi kanan.

- Periksa semua scupper plug sudah tertutup rapat.

- Periksa semua baut dan mur rapat dan kencangkan.

- Periksa spill box siap pakai dan tutup steker kering.

- Periksalah pompa pencemaran minyak yang siap pakai.

- Periksa line yang digunakan, termasuk katupnya.

- Periksa kawat pembatas di posisi kanan.

- Periksa tidak ada kebocoran di manifold.

- Periksa kesemua katup yang dikoreksi.

2) Urutan dalam membongkar (mencegah polusi)

- ambil sampel manifold dari pemuatan pertama yang masuk ke dalam tangki.
- Setelah memuat sebesar satu kaki, lakukan pemberhentian sementara untuk dianalisa.

- Initial loading rate dengan maksimal $1 \mathrm{~m} / \mathrm{sec} \quad(113$ $\mathrm{m} 3 / \mathrm{hrs}$ )

- Periksa barang yang sudah masuk ke dalam pelabuhan.

- memuat avtur +/- $22000 \mathrm{KL}$.

- Sebelum tooping up dan tooping off, buka valve ke tangki selanjutnya.

- Max. Loading rate adalah $1000 \mathrm{~m} 3 / \mathrm{hrs}$.

- The topping up dan topping off dari muatan avtur bandingkan dengan stowage plan yang telah dibuat.

- satu jam sebelum topping up dari masing-masing tangki, hubungi mualim satu.

- Hubungi mualim satu jika ada keragu-raguan.

3) Tindakan jika over flow

- Hentikan aktivitas memuat dan tutup valve.

- Bunyikan alarm.

- Temukan keadaan darurat dan bahaya yang sedang terjadi.

- Informasikan ke Nakhoda dengan segera.

- Informasikan kepada otoritas pelabuhan setempat biasanya melalui staf terminal.

- Personil yang tidak penting dari daerah tersebut dilarang untuk mendekat.

- Tutup semua pintu akses akomodasi dan hentikan semua ventilasi sirkuit tertutup.

- Tim darurat dan tim cadangan, berdiri untuk mengumpulkan/memompa tumpahan cargo ke tangki kosong/slop tank. 
- Semua tim harus menggunakan setelan kimia dengan benar.

- Atur mesin utama dan roda kemudi untuk dibawa ke posisi stand by.

4) Komunikasi

- Hubungi pelabuhan darat : hubungi orang yang sedang melakukan dinas jaga saat di pelabuhan.

- Terminal darurat : Loading Master VHF Ch. 09.

- Agen : Operasi Pertamina VHF Ch. 09.

- Pelabuhan Cilacap : Pelabuhan Cilacap VHF Ch. 12.

5) Discharging Sequence

- Membongkar (+/- 220000 KL).

- Maksimal rate bongkar (1000 $\mathrm{KL} / \mathrm{hrs}$ ) dan maksimal tekanan memuat $(5 \mathrm{~kg} / \mathrm{cm} 2)$.

- Nominasi tangki muatan : $1 \mathrm{P} / \mathrm{S}, 2 \mathrm{P} / \mathrm{S}, 3 \mathrm{P} / \mathrm{S}, 4 \mathrm{P} / \mathrm{S}, 5 \mathrm{P} / \mathrm{S}$, dan $6 \mathrm{P} / \mathrm{S}$.

- Tetap dalam posisi menyala atau berjalan untuk semua high \& overfill alarm.

- Hentikan memuat dengan segera jika terdapat kebocoran.

2. Besarnya muatan avtur yang dimuat dan dibongkar di MT. Sinar Emas

Pendistribusian avtur yang dilakukan di kapal MT. Sinar Emas periode bulan Januari-Juli 2016 dengan membawa muatan avtur dari pelabuhan muat Cilacap menuju ke pelabuhan bongkar ke beberapa sektor daerah bongkar. berikut ini data pelabuhan muat dari bulan Januari-Juli 2016.

Tabel 2. Pelabuhan Muat

\begin{tabular}{|c|l|l|c|l|}
\hline No. & $\begin{array}{c}\text { Nama } \\
\text { Pelabuhan }\end{array}$ & Tanggal & $\begin{array}{c}\text { No. } \\
\text { Voyage }\end{array}$ & Muatan \\
\hline 1 & Cilacap & $14-J a n-16$ & $01 / \mathrm{L} / 2016$ & Avtur \\
\cline { 2 - 4 }
\end{tabular}

\begin{tabular}{|c|c|c|c|c|}
\hline 2 & Cilacap & 24-Jan-16 & $02 / \mathrm{L} / 2016$ & Avtur \\
\hline 3 & Cilacap & 03-Jan-16 & 03/L/2016 & Avtur \\
\hline 4 & Cilacap & 19-Feb-16 & $04 / \mathrm{L} / 2016$ & Avtur \\
\hline 5 & Cilacap & $\begin{array}{c}\text { 01-Mar- } \\
16\end{array}$ & $05 / \mathrm{L} / 2016$ & Avtur \\
\hline 6 & Cilacap & $\begin{array}{c}\text { 10-Mar- } \\
16\end{array}$ & $06 / \mathrm{L} / 2016$ & Avtur \\
\hline 7 & Cilacap & $\begin{array}{c}\text { 21-Mar- } \\
16 \\
\end{array}$ & 07/L/2016 & Avtur \\
\hline 8 & Cilacap & 02-Apr-16 & 08/L/2016 & Avtur \\
\hline 9 & Cilacap & 12-Apr-16 & 09/L/2016 & Avtur \\
\hline 10 & Cilacap & 25-Apr-16 & $10 / \mathrm{L} / 2016$ & Avtur \\
\hline 11 & Cilacap & 10-Mei-16 & $11 / \mathrm{L} / 2016$ & Avtur \\
\hline 12 & Cilacap & 23-Mei-16 & $12 / \mathrm{L} / 2016$ & Avtur \\
\hline 13 & Cilacap & 05-Jun-16 & $13 / \mathrm{L} / 2016$ & Avtur \\
\hline 14 & Cilacap & 13-Jun-16 & $14 / \mathrm{L} / 2016$ & Avtur \\
\hline 15 & Cilacap & 26-Jun-16 & $15 / \mathrm{L} / 2016$ & Avtur \\
\hline 16 & Cilacap & 10-Jul-16 & $16 / \mathrm{L} / 2016$ & Avtur \\
\hline 17 & Cilacap & $\begin{array}{c}\text { 01-Agu- } \\
16\end{array}$ & $17 / \mathrm{L} / 2016$ & Avtur \\
\hline
\end{tabular}

Dari tabel data di atas peneliti dapat simpulkan bahwa terdapat satu pelabuhan muat sebanyak 17 kali pemuatan yaitu di pelabuhan Cilacap.

Tabel 3. Pelabuhan Bongkar

\begin{tabular}{|c|c|c|c|c|}
\hline No. & $\begin{array}{c}\text { Nama } \\
\text { Pelabuhan }\end{array}$ & Tanggal & No. Voyage & Muatan \\
\hline 1 & $\begin{array}{l}\text { SPM } \\
\text { Cengkareng }\end{array}$ & 17-Jan-16 & $01 / \mathrm{D} / 2016$ & Avtur \\
\hline 2 & $\begin{array}{l}\text { SPM } \\
\text { Cengkareng }\end{array}$ & 27-Jan-16 & $02 / \mathrm{D} / 2016$ & Avtur \\
\hline 3 & Wayame & 08 -Feb-16 & 03/D1/2016 & Avtur \\
\hline 4 & $\begin{array}{l}\text { SPM } \\
\text { Cengkareng }\end{array}$ & $16-$ Feb-16 & 03/D2/2016 & Avtur \\
\hline 5 & $\begin{array}{l}\text { SPM } \\
\text { Cengkareng }\end{array}$ & 23 -Feb-16 & $04 / \mathrm{D} / 2016$ & Avtur \\
\hline 6 & $\begin{array}{l}\text { SPM } \\
\text { Cengkareng }\end{array}$ & 04-Mar-16 & $05 / \mathrm{D} / 2016$ & Avtur \\
\hline 7 & Surabaya & 14-Mar-16 & 06/D1/2016 & Avtur \\
\hline 8 & $\begin{array}{l}\text { SPM } \\
\text { Cengkareng }\end{array}$ & 18-Mar-16 & 06/D2/2016 & Avtur \\
\hline 9 & $\begin{array}{l}\text { SPM } \\
\text { Cengkareng }\end{array}$ & 25-Mar-16 & $07 / \mathrm{D} / 2016$ & Avtur \\
\hline 10 & Surabaya & 06-Apr-16 & 08/D1/2016 & Avtur \\
\hline 11 & $\begin{array}{l}\text { SPM } \\
\text { Cengkareng }\end{array}$ & 10-Apr-16 & 08/D2/2016 & Avtur \\
\hline 12 & $\begin{array}{l}\text { SPM } \\
\text { Cengkareng }\end{array}$ & 19-Apr-16 & $09 / \mathrm{D} / 2016$ & Avtur \\
\hline 13 & $\begin{array}{l}\text { SPM } \\
\text { Cengkareng }\end{array}$ & 28-Apr-16 & $10 / \mathrm{D} / 2016$ & Avtur \\
\hline
\end{tabular}




\begin{tabular}{|c|l|c|l|l|}
\hline 14 & Wayame & $15-M e i-16$ & $11 / \mathrm{D} 1 / 2016$ & Avtur \\
\hline 15 & $\begin{array}{l}\text { SPM } \\
\text { Cengkareng }\end{array}$ & 20-Mei-16 & $11 / \mathrm{D} 2 / 2016$ & Avtur \\
\hline 16 & $\begin{array}{l}\text { SPM } \\
\text { Cengkareng }\end{array}$ & 28-Mei-16 & $12 / \mathrm{D} / 2016$ & Avtur \\
\hline 17 & Surabaya & 08-Juni-16 & $13 / \mathrm{D} 1 / 2016$ & Avtur \\
\hline 18 & $\begin{array}{l}\text { SPM } \\
\text { Cengkareng }\end{array}$ & 12 -Jun-16 & $13 / \mathrm{D} 2 / 2016$ & Avtur \\
\hline 19 & $\begin{array}{l}\text { SPM } \\
\text { Cengkareng }\end{array}$ & 16-Jun-16 & $14 / \mathrm{D} / 2016$ & Avtur \\
\hline 20 & Wayame & 30-Juni-16 & 15/D1/2016 & Avtur \\
\hline 21 & $\begin{array}{l}\text { SPM } \\
\text { Cengkareng }\end{array}$ & 05-Juli-16 & 15/D2/2016 & Avtur \\
\hline
\end{tabular}

\begin{tabular}{|c|l|c|c|l|}
\hline 22 & Surabaya & 13-Jul-16 & $16 / \mathrm{D} 1 / 2016$ & Avtur \\
\hline 23 & $\begin{array}{l}\text { SPM } \\
\text { Cengkareng }\end{array}$ & 22-Jul-16 & 16/D2/2016 & Avtur \\
\hline
\end{tabular}

Dari Tabel 3 MT. Sinar Emas melakukan pembongkaran muatan avtur sebanyak 23 kali pembongkaran dengan 3 pelabuhan bongkar yang berbeda.

Tabel 4. Daerah Bongkar

\begin{tabular}{|c|l|c|c|c|}
\hline No. & \multicolumn{1}{|c|}{ Daerah } & $\begin{array}{c}\text { Nama } \\
\text { Pelabuhan }\end{array}$ & Kehadiran & Muatan \\
\hline 1 & Cengkareng & $\begin{array}{c}\text { SPM } \\
\text { Cengkareng }\end{array}$ & 16 kali & Avtur \\
\hline 2 & Surabaya & $\begin{array}{c}\text { Semampir } \\
\text { Surabaya }\end{array}$ & 4 kali & Avtur \\
\hline 3 & $\begin{array}{l}\text { Wayame, } \\
\text { Ambon }\end{array}$ & $\begin{array}{c}\text { Wayame, } \\
\text { Ambon }\end{array}$ & 3 kali & Avtur \\
\hline
\end{tabular}

Dari data tabel di atas jumlah total muatan avtur yang dibongkar MT. Sinar Emas di tiga pelabuhan sebanyak 627,329.388 dari bulan Januari-Juli 2016, muatan avtur paling banyak dibongkar di SPM Cengkareng sebanyak 276,125.149 kemudian Surabaya sebanyak 380,056.145 dan pelabuhan dengan nilai bongkar terakhir adalah Wayame sebesar 16,148.094. Dari setiap perhitungan bongkar dibagi dengan rate kapal guna pemaksimalan transfer muatan di tangki muatan darat menyesuaikan dengan daya

Dari Tabel 4 MT. Sinar Emas melakukan pembongkaran muatan avtur di 3 daerah. Tiga daerah titik tersebut antara lain Cengkareng Jakarta, Surabaya, dan Wayame.

Tabel 5. Jumlah Muatan yang dibongkar

\begin{tabular}{|c|c|c|}
\hline No & Pelabuhan & $\begin{array}{c}\text { Jumlah } \\
\text { Keseluruhan }\end{array}$ \\
\hline 1 & Cengkareng & $276,125.149$ \\
\hline 2 & Surabaya & $380,056.145$ \\
\hline 3 & Wayame & $16,148.094$ \\
\hline \multirow{2}{*}{} & TOTAL & $\mathbf{6 2 7 , 3 2 9 . 3 8 8}$ \\
\cline { 2 - 3 } & \multicolumn{2}{|c}{} \\
\cline { 2 - 3 }
\end{tabular}

tahan pompa dan pipa kapal serta pipa darat.

3. Perbedaan jumlah muatan yang dibongkar di MT. Sinar Emas

Perhitungan jumlah muatan dilakukan untuk mengetahui quantity minyak sebelum pelaksanaan pembongkaran digunakan sebagai pembanding antara jumlah muatan di kapal setelah pembongkaran di pelabuhan muat dengan jumlah muatan di kapal sebelum pelaksanaan pembongkaran di pelabuhan bongkar. 
Tabel 6. Perbedaan jumlah muatan yang dibongkar

\begin{tabular}{|c|c|c|c|c|}
\hline NO & VOYAGE & $\begin{array}{c}\text { B/L } \\
\text { FIGURES } \\
\text { (KL } \\
\text { OBSV) }\end{array}$ & $\begin{array}{c}\text { SHIP'S } \\
\text { FIGURE } \\
\text { (KL } \\
\text { OBSV) }\end{array}$ & $\begin{array}{l}\text { DIFFE } \\
\text { RENCE }\end{array}$ \\
\hline 1 & $01 / \mathrm{L} / 2016$ & $22,199.112$ & $22,187.687$ & -11.425 \\
\hline 2 & $01 / \mathrm{D} / 2016$ & $22.199,11$ & $22,187.687$ & $-28,325$ \\
\hline 3 & $02 / \mathrm{L} / 2016$ & $22,129.045$ & $22,129.045$ & 0,421 \\
\hline 4 & $02 / \mathrm{D} / 2016$ & $22.128,62$ & $22.129,05$ & $-12,831$ \\
\hline 5 & $03 / \mathrm{L} / 2016$ & $22,031.435$ & $22,005.810$ & -25.626 \\
\hline 6 & 03/D1/2016 & $5,349.148$ & $5,252.763$ & -96.385 \\
\hline 7 & 03/D2/2016 & $16,682,740$ & $16,681.251$ & $-0,265$ \\
\hline 8 & $04 / L / 2016$ & $22,096.612$ & $22,136.826$ & 40.214 \\
\hline 9 & $04 / \mathrm{D} / 2016$ & $22,096.612$ & $22,136.826$ & $-15,334$ \\
\hline 10 & $05 / \mathrm{L} / 2016$ & $22,052.818$ & $22,039.972$ & -12.846 \\
\hline 11 & $05 / \mathrm{D} / 2016$ & $22,052.818$ & $22,039.972$ & $-4,568$ \\
\hline 12 & $06 / L / 2016$ & $22,243.132$ & $22,233.706$ & -9.426 \\
\hline 13 & 06/D1/2016 & $10,104.899$ & $10,062.172$ & -42.727 \\
\hline 14 & 06/D2/2016 & $10,104.90$ & $10,062.17$ & -23.227 \\
\hline 15 & 07/L/2016 & $22,210.635$ & $22,219.407$ & 8.772 \\
\hline 16 & $07 / \mathrm{D} / 2016$ & $22,093.206$ & $22,060.800$ & -10.526 \\
\hline 17 & $08 / \mathrm{L} / 2016$ & $22,093.206$ & $22,0060.800$ & -32.406 \\
\hline 18 & $08 / \mathrm{D} 1 / 2016$ & $7,135.471$ & $7,069.025$ & -66.446 \\
\hline 19 & 08/D2/2016 & $14,001.022$ & $13,998.694$ & $-39,06$ \\
\hline 20 & $09 / \mathrm{L} / 2016$ & $22,141.930$ & $22,135.620$ & -6.310 \\
\hline 21 & $09 / \mathrm{D} / 2016$ & $22,141.930$ & $22,135.620$ & -6.366 \\
\hline 22 & $10 / \mathrm{L} / 2016$ & $22,019.725$ & $22,011.164$ & -8.561 \\
\hline 23 & $10 / \mathrm{D} / 2016$ & $22,019.725$ & $22,011.164$ & -20.708 \\
\hline 24 & $11 / \mathrm{L} / 2016$ & $22,190.432$ & $22,195.277$ & 4.845 \\
\hline 25 & 11/D1/2016 & $5,573.021$ & $5,571.956$ & $-1,141$ \\
\hline 26 & $11 / \mathrm{D} 2 / 2016$ & $16,620.087$ & $16,619.824$ & $-0,834$ \\
\hline 27 & $12 / \mathrm{L} / 2016$ & $22,015.793$ & $22,008.940$ & $-6,853$ \\
\hline 28 & $12 / \mathrm{D} / 2016$ & $22,015.793$ & $22,008.940$ & -17.074 \\
\hline 29 & $13 / \mathrm{L} / 2016$ & $22,026.164$ & $22,026.006$ & $-0,158$ \\
\hline 30 & $13 / \mathrm{D} 1 / 2016$ & $10,976.432$ & $10,974.182$ & $-2,086$ \\
\hline 31 & $13 / \mathrm{D} 2 / 2016$ & $10,999.976$ & $10,998.995$ & $-0,2$ \\
\hline 32 & $14 / \mathrm{L} / 2016$ & $21,997.144$ & $21,993.406$ & -3.738 \\
\hline 33 & $14 / \mathrm{D} / 2016$ & $21,997.144$ & $21,993.406$ & 10.386 \\
\hline 34 & $15 / \mathrm{L} / 2016$ & $22,159.828$ & $22,156.187$ & -3.641 \\
\hline 35 & $15 / \mathrm{D} 1 / 2016$ & $5,325.578$ & $5,323.375$ & $-2,495$ \\
\hline 36 & $15 / \mathrm{D} 2 / 2016$ & $16,830.001$ & $16,829.565$ & $-1,453$ \\
\hline 37 & $16 / \mathrm{L} / 2016$ & $22,136.627$ & $22,106.219$ & -30.408 \\
\hline 38 & $16 / \mathrm{D} 1 / 2016$ & $9,959.877$ & $9,950.766$ & $-2,315$ \\
\hline 39 & $16 / \mathrm{D} 2 / 2016$ & $12,149.073$ & $12,147.328$ & $-2,344$ \\
\hline 40 & $17 / \mathrm{L} / 2016$ & $21.928,637$ & $21.932,071$ & 3.434 \\
\hline
\end{tabular}

\section{DISKUSI}

A. Langkah-langkah yang dilakukan untuk mendistribusikan muatan avtur proses bongkar muat di 3 pelabuhan.

Dalam kuesioner yang telah diberikan kepada perwira di MT. Sinar Emas, terdapat penilaian untuk tiap-tiap faktor yang mempunyai hubungan dalam pendistribusian muat dan bongkar muatan avtur.

Tabel 7. Langkah-langkah pelaksanaan untuk mendistribusikan muatan avtur proses bongkar muat

\begin{tabular}{|c|l|}
\hline No. & \multicolumn{1}{|c|}{ Langkah-langkah Pelaksanaan } \\
\hline 1 & $\begin{array}{l}\text { Mempersiapkan kapal dengan tank cleaning kapal } \\
\text { beserta alat muat dan bongkar. }\end{array}$ \\
\hline 2 & $\begin{array}{l}\text { Menyiapkan perencanaan dengan stowage plan } \\
\text { bongkar sesuai dengan permintaan pada cargo } \\
\text { manifest. }\end{array}$ \\
\hline 3 & $\begin{array}{l}\text { Melaksanakan koordinasi oleh pihak kapal (intern) } \\
\text { dan pihak darat (extern). }\end{array}$ \\
\hline 4 & $\begin{array}{l}\text { Melaksanakan pelaksanaan pendistribusian muatan } \\
\text { avtur harus sesuai dengan loading dan discharging } \\
\text { instruction.. }\end{array}$ \\
\hline 5 & $\begin{array}{l}\text { Setelah selesai pemuatan dan sebelum } \\
\text { melaksanakan pembongkaran harus melakukan } \\
\text { evaluasi dengan perhitungan muatan oleh mualim } \\
\text { satu bersama dengan loading master dan survyor. }\end{array}$ \\
\hline
\end{tabular}

1. Persiapan distribusi muat dan bongkar muatan avtur dengan tank cleaning kapal beserta alat muat dan bongkar. Tank cleaning yang dilakukan di kapal MT. Sinar Emas harus sesuai dengan pedoman yang diberikan oleh pihak Pertamina setelah melakukan kegiatan membongkar. Para pihak kapal dan loading master beserta survyor harus mengecek tangki-tangki tersebut apakah masing-masing tangki sudah dalam keadaan kering dan siap untuk dimuat. Dengan cara mengecek tangki kapal tidak ada genangan-genangan minyak. Kemudian cek tangki kapal bebas dari gas. Dan mengecek pipapipa kapal dalam keadaan bersih dan kondisi kering.

2. Menyiapkan perencanaan dengan stowage plan bongkar yang sesuai dengan cargo manifest. 
Sebagai perencanaan agar proses distribusi muat bongkar muatan avtur di MT. Sinar Emas dapat berjalan sesuai dengan prosedural maka mualim satu membuat stowage plan. Stowage plan adalah panduan yang dibuat oleh mualim satu selaku perwira penanggung jawab muatan disetujui oleh Nakhoda dan pihak terminal untuk membantu pelaksanaan pemuatan bagi setiap perwira jaga.

3. Melaksanakan koordinasi oleh pihak kapal (intern) dan pihak darat (extern). Kegiatan extern yang dilakukan adalah safety meeting bagi seluruh crew kapal guna menghindari bahaya yang akan terjadi di atas kapal. Setelah melakukan safety meeting seluruh crew kapal melakukan latihan-latihan drill yang telah ditentukan oleh Mualim tiga. Kegiatan intern yang dilakukan yaitu saat loading master dan survyor naik ke atas kapal untuk mengecek masing-masing tangki, bahwa tangki tersebut benar-benar dalam keadaan kering dan siap untuk dimuat.

4. Melaksanakan pelaksanaan pendistribusian muatan avtur harus sesuai dengan loading dan discharging instruction.

- Persiapan pelaksanaan distribusi pada saat melaksanakan pembongkaran yaitu:

a. Menjalankan pompa muatan

b. Pengawasan kegiatan

c. Menjalankan pompa pengeringan

- Pelaksanaan Muat MT. Sinar Emas Pelaksanaan proses pemuatan avtur di MT. Sinar Emas 100\% dilakukan di Pelabuhan Cilacap dengan jumlah pemuatan sebanyak 17 kali.

- Pelaksanaan proses bongkar MT Sinar. Emas

Pelaksanaan proses pembongkaran avtur di MT. Sinar Emas adalah dengan 3 pelabuhan berbeda, yang letaknya di wilayah Indonesia
Bagian Barat dan wilayah Indonesia Bagian Timur, dari tiga pelabuhan bongkar satu diantaranya terletak pada Indonesia Bagian Barat yaitu SPM Cengkareng, dan dua pelabuhan terletak di Indonesia Bagian Timur yaitu Surabaya dan Wayame.

- Gambaran pelaksanaan muat bongkar MT. Sinar Emas.

MT. Sinar Emas melakukan pemuatan di satu pelabuhan muat yang sebanyak 17 kali. Seluruh pemuatan dilakukan di pelabuhan Cilacap dengan tiga pelabuhan bongkar yaitu SPM Cengkareng, Surabaya, dan Wayame.

5. Melakukan evaluasi dengan perhitungan muatan oleh Mualim satu bersama dengan Loading Master dan Survyor.

a. MEMUAT

1) Sounding Cargo

2) Calculation Cargo

3) Clearence Cargo Document and Ship Document
a) Mate's Receipt
b) Bill of Lading
c) Cargo Manifest
d) Delivery Order
e) Shipping Instruction

b. MEMBONGKAR

1) Perhitungan muatan

2) Clearence cargo document

B. Besarnya muatan avtur yang dimuat dan dibongkar di kapal MT. Sinar Emas

Dihitung dengan menggunakan tabel compartement logsheet. Dengan perhitungan compartement logsheet peneliti dapat menentukan besarnya muatan yang terdapat di kapal. Besarnya muatan tersebut akan dievaluasi dengan cara menghitung semua seberapa besar muatan yang hilang saat melakukan muat dan bongkar. Cara perhitungan transport lost terbagi menjadi 4 bagian yaitu R1, R2, R3, dan R4. 
R1 adalah selisih muatan yang hilang saat memuat di pelabuhan muat. Muatan yang hilang tersebut didapat dari perbandingan antara nilai actual yang didapat di kapal, dengan nilai BL yang dikeluarkan oleh Pertamina.

$\mathrm{R} 2$ adalah jumlah muatan yang hilang saat pengirim melakukan pengiriman muatan, dari pelabuhan muat ke pelabuhan bongkar. R2 didapatkan dari perbandingan antara jumlah muatan sebelum bongkar di pelabuhan bongkar, kemudian dikurangi dengan jumlah muatan setelah melakukan pemuatan di pelabuhan muat dan dibagi dengan jumlah BL. Transport lost untuk R2 tidak boleh lebih dari $0.09 \%$.

R3 adalah besarnya selisih muatan antara muatan yang dikirim oleh pihak kapal, dengan muatan yang diterima oleh pihak darat dan Pertamina. Untuk perhitungan R3 didapat dari penerimaan darat dikurangi besarnya nilai muatan sebelum melakukan bongkar muatan, kemudian dibagi oleh angka BL.

R4 adalah jumlah selisih keseluruhan muatan yang tertera pada BL dengan muatan yang diterima oleh pelabuhan bongkar. R4 juga dapat dikatakan hasil penjumlahan antara R1, R2, dan R3.

Tabel 8. Perbedaan muatan di setiap pelabuhan

\begin{tabular}{|c|c|c|c|c|c|}
\hline No. & Pelabuhan & $\begin{array}{c}\text { Ship } \\
\text { Figure }\end{array}$ & BL & $\begin{array}{c}\text { Jumlah } \\
\text { Diff. } \\
\text { (KL } \\
\text { Obs.) }\end{array}$ & $\begin{array}{c}\text { R1 } \\
(\%)\end{array}$ \\
\hline 1 & Cilacap & $22.092,832$ & $22.098,344$ & -5.125 & 0.02 \\
\hline
\end{tabular}

Tabel di atas menyebutkan bahwa dari jumlah keseluruhan muatan saat melaksanakan pemuatan di pelabuhan Cilacap terdapat $5.125 \mathrm{KL}$ avtur yang hilang selama periode bulan Januari-Juli 2016. Dari pelabuhan muat Cilacap, muatan yang hilang masih dalam batas

Tabel 9. Perbandingan muatan R1, R2,R3, dan R4

\begin{tabular}{|c|l|c|c|c|c|}
\hline \multirow{2}{*}{ No. } & \multirow{2}{*}{ Voyage } & \multicolumn{4}{|c|}{ Transport loss } \\
\cline { 3 - 6 } & & $\mathbf{R 1}$ & $\mathbf{R 2}$ & $\mathbf{R 3}$ & $\mathbf{R 4}$ \\
\hline 1 & $01 / \mathrm{L} / 2016$ & -0.05 & & & \\
\hline 2 & $01 / \mathrm{D} / 2016$ & & -0.13 & -0.06 & -0.23 \\
\hline 3 & $02 / \mathrm{L} / 2016$ & 0.0 & & & \\
\hline 4 & $02 / \mathrm{D} / 2016$ & & -0.06 & -0.03 & -0.09 \\
\hline 5 & $03 / \mathrm{L} / 2016$ & -0.12 & & & \\
\hline 6 & $\begin{array}{l}03 / \mathrm{D} 1 / 201 \\
6\end{array}$ & & -0.35 & -0.02 & -2.17 \\
\hline 7 & $\begin{array}{l}03 / \mathrm{D} 2 / 201 \\
6\end{array}$ & & -0.03 & -0.05 & -0.09 \\
\hline 8 & $04 / \mathrm{L} / 2016$ & 0.18 & & & \\
\hline 9 & $04 / \mathrm{D} / 2016$ & & -0.07 & -0.05 & 0.06 \\
\hline 10 & $05 / \mathrm{L} / 2016$ & -0.06 & & & \\
\hline 11 & $05 / \mathrm{D} / 2016$ & & -0.02 & -0.04 & -0.11 \\
\hline
\end{tabular}

toleransi yang diberikan oleh Pertamina. Batas toleransi yang diberikan oleh pihak Pertamina adalah $<0.2 \%$, kesimpulan peneliti adalah besarnya pemuatan di MT. Sinar Emas masih dalam batas yang wajar dan aman.

\begin{tabular}{|c|l|l|l|l|l|}
\hline 12 & $06 / \mathrm{L} / 2016$ & -0.04 & & & \\
\hline 13 & $\begin{array}{l}06 / \mathrm{D} 1 / 201 \\
6\end{array}$ & & -0.18 & -0.01 & -0.61 \\
\hline 14 & $\begin{array}{l}06 / \mathrm{D} 2 / 201 \\
6\end{array}$ & & -0.17 & -0.01 & -0.60 \\
\hline 15 & $07 / \mathrm{L} / 2016$ & 0.04 & & & \\
\hline 16 & $07 / \mathrm{D} / 2016$ & & -0.05 & -0.02 & -0.22 \\
\hline 17 & $08 / \mathrm{L} / 2016$ & -0.15 & & & \\
\hline 18 & $\begin{array}{l}08 / \mathrm{D} 1 / 201 \\
6\end{array}$ & & -0.14 & -0.01 & -1.09 \\
\hline 19 & $\begin{array}{l}08 / \mathrm{D} 2 / 201 \\
6\end{array}$ & & -0.90 & -0.05 & -0.97 \\
\hline 20 & $09 / \mathrm{L} / 2016$ & -0.03 & & & \\
\hline 21 & $09 / \mathrm{D} / 2016$ & & -0.03 & -0.01 & -0.06 \\
\hline 22 & $10 / \mathrm{L} / 2016$ & -0.04 & & & \\
\hline 23 & $10 / \mathrm{D} / 2016$ & & -0.09 & -0.06 & -0.19 \\
\hline 24 & $11 / \mathrm{L} / 2016$ & 0.02 & & & \\
\hline 25 & $\begin{array}{l}11 / \mathrm{D} 1 / 201 \\
6\end{array}$ & & -0.02 & -0.02 & -0.06 \\
\hline 26 & $11 / \mathrm{D} 2 / 201$ & & -0.01 & -0.01 & -0.02 \\
\hline
\end{tabular}




\begin{tabular}{|c|c|c|c|c|c|}
\hline & 6 & & & & \\
\hline 27 & 12/L/2016 & -0.03 & & & \\
\hline 28 & $12 / \mathrm{D} / 2016$ & & -0.08 & -0.05 & -0.16 \\
\hline 29 & 13/L/2016 & -0.16 & & & \\
\hline 30 & $\begin{array}{l}13 / \mathrm{D} 1 / 201 \\
6\end{array}$ & & -0.02 & -0.02 & -0.06 \\
\hline 31 & $\begin{array}{l}13 / \mathrm{D} 2 / 201 \\
6\end{array}$ & & 0.00 & -0.04 & -0.05 \\
\hline 32 & $14 / \mathrm{L} / 2016$ & -0.02 & & & \\
\hline 33 & $14 / D / 2016$ & & 0.05 & -0.01 & -0.02 \\
\hline 34 & $15 / \mathrm{L} / 2016$ & $\begin{array}{l}- \\
3.641\end{array}$ & & & \\
\hline 35 & $\begin{array}{l}15 / \mathrm{D} 1 / 201 \\
6\end{array}$ & & -0.05 & -0.02 & -0.11 \\
\hline 36 & $\begin{array}{l}15 / \mathrm{D} 2 / 201 \\
6\end{array}$ & & -0.01 & -0.04 & -0.05 \\
\hline 37 & $16 / \mathrm{L} / 2016$ & $\begin{array}{c}- \\
30.40 \\
8\end{array}$ & & & \\
\hline 38 & $\begin{array}{l}16 / \mathrm{D} 1 / 201 \\
6\end{array}$ & & -0.02 & -0.01 & -0.13 \\
\hline 39 & $\begin{array}{l}16 / \mathrm{D} 2 / 201 \\
6\end{array}$ & & $-0,02$ & -0.02 & -0.05 \\
\hline 40 & 17/L/2016 & 0.02 & & & \\
\hline
\end{tabular}

Pada tabel di atas telah dijelaskan masing-masing dari perbandingan muatan yang hilang selama kegiatan pemuatan sampai kegiatan pembongkaran.

Tabel 4.3 Nilai Rata-rata R1, R2, R3, dan R4

\begin{tabular}{|c|c|c|c|c|}
\hline No & $\begin{array}{c}\text { Varia } \\
\text { bel }\end{array}$ & $\begin{array}{c}\text { Nilai } \\
\text { Terendah } \\
\text { (dalam } \\
\text { \%) }\end{array}$ & $\begin{array}{c}\text { Nilai } \\
\text { Tertinggi } \\
\text { (dalam } \\
\text { \%) }\end{array}$ & $\begin{array}{c}\text { Rata- } \\
\text { rata } \\
\text { (dalam } \\
\text { \%) }\end{array}$ \\
\hline 1 & R1 & -0.15 & 0.18 & $-0,03$ \\
\hline 2 & R2 & -0.90 & 0.05 & -0.10 \\
\hline 3 & R3 & -0.06 & -0.01 & -0.03 \\
\hline 4 & R4 & -2.17 & 0.06 & -0.31 \\
\hline
\end{tabular}

Nilai terbesar dan terkecil yang peneliti nyatakan dalam presentase pada tabe di atas bukanlah menyatakan besarnya jumlah muatan, karena jika muatan yang dimuat dan dibongkar lebih besar maka presentase muatan yang hilang atau toleransi kuantitas muatan akan menjadi lebih besar.

C. Perbedaan muatan avtur saat dimuat dan dibongkar di kapal MT. Sinar Emas

Perbedaan nilai muatan dapat terjadi karena sebuah kewajaran, asalkan sesuai dengan batas toleransi. Faktor-faktor terjadinya perbedaan muatan adalah keadaan pipa pemuatan pembongkaran, apakah saat dilakukan kegiatan muat dan bongkar terisi atau kosong. Kedua, keadaan tangki apakah saat pemuatan ataupun pembongkaran pada tangki terdapat kegiatan lain. Yang ketiga adalah penguapan, yang kaitannya dengan temperature avtur, density avtur dan pengukuran pada waktu proses sounding, faktor yang lain adalah kebocoran pada tangki atau pipa-pipa penyalur avtur.

\section{KESIMPULAN}

Dari keseluruhan pembahasan yang telah dipaparkan pada bab terdahulu mengenai analisis distribusi muat dan bongkar muatan avtur di kapal MT. Sinar Emas peneliti dapat menyimpulkan sebagai berikut:

1. Langkah-langkah yang dilakukan untuk mendistribusikan muatan avtur proses bongkar dan muat muatan avtur di 3 pelabuhan.

Langkah-langkah yang harus dilakukan setelah dilakukan wawancara dengan beberapa responden di kapal yaitu mulai dari persiapan, perencanaan, koordinasi, pelaksanaan dan evaluasi kapal.

2. Besarnya muatan yang dimuat dan dibongkar di kapal MT. Sinar Emas.

Dapat disimpulkan bahwa pelabuhan muat dalam memuat muatan avtur tertinggi selama periode bulan Januari-Juli 2016 sebesar 22,243.132 KL, pelabuhan bongkar terbesar adalah SPM Cengkareng dengan jumlah muatan avtur tertinggi yang dibongkar mencapai 22,187.687 KL dan daerah dengan jumlah bongkar terkecil adalah Wayame sebesar 5,252.763 KL. Dari data tersebut membuktikan bahwa tingkat kebutuhan avtur sebagai bahan bakar pesawat udara paling banyak dibutuhkan di daerah Jawa Barat tepatnya di daerah Cengkareng. 
3. Terjadinya perbedaan muatan avtur pada saat dimuat dan dibongkar oleh MT. Sinar Emas.

Perbedaan nilai muatan dapat terjadi karena sebuah kewajaran, asalkan sesuai dengan batas toleransi. Faktor-faktor terjadinya perbedaan muatan adalah keadaan pipa pemuatan pembongkaran, apakah saat dilakukan kegiatan muat dan bongkar terisi atau kosong. Kedua, keadaan tangki apakah saat pemuatan ataupun pembongkaran pada tangki terdapat kegiatan lain. Yang ketiga adalah penguapan, yang kaitannya dengan temperature avtur, density avtur dan pengukuran pada waktu proses sounding, faktor yang lain adalah kebocoran pada tangki atau pipa-pipa penyalur avtur.

Setelah memperhatikan kesimpulan tersebut di atas maka peneliti memberikan saran yang sekiranya dapat bermanfaat dan berguna bagi awak kapal MT. Sinar Emas dan pembaca secara umum, dalam menganalisis perhitungan muat bongkar avtur di pelabuhan muat maupun pelabuhan bongkar. adapun saran-saran tersebut adalah:

1. Dalam setiap langkah-langkah harus dengan melakukan persiapan fisik diantaranya persiapan tangki kapal, cargo pipe line, alat muat bongkar, alat bantu bongkar muat, dan alat keselamatan. Persiapan administrasi yang dilakukan adalah safety check list, dan ship document. Ship document ini terdiri dari mate's receipts, bill of lading, cargo manifest, delivery order, dan shipping instruction. Selanjutnya perencanaan dengan membuat stowage plan bongkar sesuai dengan permintaan pada cargo manifest. Berkoordinasi dengan pihak darat (intern) dan pihak kapal (extern). Melaksanakan pelaksanaan pendistribusian muatan avtur harus sesuai dengan loading dan discharging instruction, dan setelah selesai pemuatan dan sebelum melaksanakan pembongkaran harus melakukan evaluasi dengan perhitungan muatan oleh Mualim satu bersama dengan Loading Master dan Survyor. Mulai dari persiapan, perencanaan, kordinasi, pelaksanaan dan evaluasi kapal. Yang melakukan muat bongkar memiliki peranan dalam kelancaran proses distribusi, maka perlu adanya peningkatan manajemen pelabuhan agar segala proses muat dan bongkar kapal meningkat.

2. Perlunya perhitungan muatan untuk mengetahui besarnya muatan yang terdapat di kapal, juga untuk memantau pergerakan muatan secara baik dan benar. Perhitungan muatan tersebut digunakan sebagai sistem control untuk mencegah bahaya dan kecurangan dalam dunia bisnis.

3. Pentingnya pemahaman analisis muat bongkar avtur saat pemuatan dan pembongkaran. Bagi awak kapal untuk menghindari kerugian, serta perlindungan bagi awak kapal dan muatan itu sendiri sesuai dengan prinsip pemuatan. Bagi para pembaca sebagai pemahaman tentang analisis bongkar muat muatan avtur dan dapat mempermudah dalam pemahaman materi dalam pelajaran penanganan dan perhitungan muatan.

\section{DAFTAR PUSTAKA}

ICS OCIMF.1996.ISGOTT ( International Safety Guide For Oil Tankers and Terminal, Fourth Edition)

Istopo. 1999. Kapal dan Muatannya, Jakarta :Koperasi karyawan BP3IP.

2008. Kapal \& Muatannya. Jakarta Utara: Koperasi Karyawan BP3IP 
Martopo, A. 2004. Penanganan dan Pengaturan Muatan. Semarang : Politeknik Ilmu Pelayaran Semarang . 2001. Penanaganan Muatan. Semarang : Politeknik Ilmu Pelayaran Semarang

Syatori, Nasehudin dan Nanang Ghozali. 2012. Metode Penelitian Kuantitatif. Bandung : Pustaka Setia

Nur, Nasution. 2008. Manajemen Transportasi. Jakarta : Ghalia Indonesia

Pendidikan dan Latihan pelayaran. 2000. Oil Tanker Familiarisation. Jakarta.
Abbas, Salim. 2004. Manajemen Transportasi. Jakarta : PT. Raja Grafindo Persada

Sugiyono. 2008. Metode Penelitian Pendidikan (Pendekatan Kuantitatif, Kualitatif, dan $R \& D)$. Bandung : CV. Alfabeta

Suryana. 2010. Metodologi Penelitian Model Praktis Penelitian Kuantitatif dan Kualitatif. Jakarta Universitas Pendidikan Indonesia.

Arikunto, Suharsimi. 2010. Prosedur Penelitian Suatu Pendekatan Praktik. Jakarta : PT.Rineka Cipta 